\title{
Work environment and job satisfaction among nurses in government tertiary hospitals in Nigeria
}

\author{
Olusegun Emmanuel Akinwale and Olusoji James George \\ Department of Business Administration, Faculty of Management Sciences, \\ University of Lagos, Akoka, Lagos, Nigeria
}

Received 25 January 2020 Revised 13 March 2020 20 March 2020 Accepted 21 March 2020

\begin{abstract}
Purpose - Job satisfaction is indispensable in the daily life of the workforce, and the mechanism that drives job satisfaction requires the attention of the management of corporate organisations. The purpose of this paper is to investigate the predictors of work environment on job satisfaction among nurses in both federal and state tertiary hospitals in Lagos State.

Design/methodology/approach - The study used the longitudinal research design to elicit information from the respondents. The research instrument used is a nursing work index scale by Aiken and Patrician which has been established to have a high internal reliability coefficient. The simple random sampling strategy was used to administer the research instrument to 364 nurses. The study used hierarchical multiple regression to analyse the data obtained.

Findings - This study discovered that all the variables collectively determined nurses job satisfaction; however, the salary was the most fundamental essential predictor that drive nurses' job satisfaction followed by advancement and promotion. All seven predictors, namely, socio-political climate; administrative and managerial support, autonomy and responsibility, salary, supervision and working condition, recognition and achievement, advancement and promotion, collectively exert positive relationship with nurses' job satisfaction. The study concluded that to retain and prevent turnover intention among nurses, and other health-care workers, the management of hospitals must pay due attention to issues relating to job satisfaction, as this is likely to increase health-care system effectiveness, boost mental and social health of the nurses.

Originality/value - This study shows that job satisfaction in the workplace comes from diverse techniques, as other factors have been proven effective other than salary in international cultures and regions, but in Nigeria, salary and career promotion take pre-eminence above other factors. This is because of Nigerian socio-cultural realities and that is another paradigm shift.
\end{abstract}

Keywords Work environment, Job satisfaction, Nurses, Government hospitals, Working condition, Promotion

Paper type Research paper

(C) Olusegun Emmanuel Akinwale and Olusoji James George. Published in Rajagiri Management Journal. Published by Emerald Publishing Limited. This article is published under the Creative Commons Attribution (CC BY 4.0) license. Anyone may reproduce, distribute, translate and create derivative works of this article (for both commercial and non-commercial purposes), subject to full attribution to the original publication and authors. The full terms of this license may be seen at http:// creativecommons.org/licences/by/4.0/legalcode

This research appreciates the tertiary hospitals in the course of filling the research instruments for giving necessary support for data collection. This research did not receive any specific grant from funding agencies in the public, commercial or not-for-profit organisations.

Data availability statement: The data that support the findings of this study are available from the corresponding author, (Akinwale, O. E.) upon reasonable request.

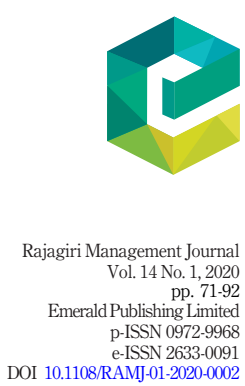


RAMJ

14,1

\section{Introduction}

Satisfaction in the workplace has played a dominant role in eliciting positive work behaviour in the Nigerian business environment. It acts as an impulse that drives productivity among the workforce, and any forward-looking organisation that wants to sustain the competitive business environment must devote the required attention to employee job satisfaction. Ugwa et al. (2014) argued that satisfying employee on the job is a determinant of individual well-being, as it enables employees to make an informed decision regarding leaving or glueing to a particular firm. In the Nigerian health-care industry, job satisfaction has been a contentious issue among health-care workers, especially in government hospitals and clinics. Owing to the challenges and risk (to life) involved, being happy in the health-care sector entails the constellation of factors for health-care employees.

Job satisfaction of employees lead to several positive behavioural outcomes at work. High job satisfaction brings about productive work behaviour. It enables employees to satisfy customers/patients. It creates customer experience at work and reduces employee turnover intention. Furthermore, the concept of satisfaction for health-care employees has described as a positive feeling of contentment that individuals obtain from their job while working for a corporate organisation (Ezeja et al., 2010). In other words, employees' job satisfaction describes an attitudinal component of employees towards their job by expressing job satisfaction as the degree to which they like or dislike the job. The moment people like and enjoy their work, they are observed to be fulfilled, productive and, such employees tend to have a high level of job satisfaction while those employees who are dissatisfied with their work will have low satisfaction with such job and may experience stress at work, burnout as well as psychological health disorders (Coker et al., 2011).

The significance of job satisfaction of nurses on patients' care, patient satisfaction, patient outcome and general health-care delivery cannot be over-emphasized, as employee's job satisfaction is essential in the daily life of the workforce. It has been established that low job satisfaction is the main basis of employee's turnover among health-care service workers (Chamal and Dilina, 2018). Low job satisfaction negatively influences the quality of service delivery and the organisational commitment of health-care employees. This may be connected with a shortage of personnel (Fitzpatrick, 2012) or psychosocial pressure. The satisfied employees seem to be highly creative and dedicated to work; they engage and absorb themselves with the goals and objectives of the organisations (Ogbolu et al., 2015). Research has reported a direct association between health-care employees' satisfaction and patients' satisfaction (Kever et al., 2018). The management of hospitals that are skilful in establishing a work environment which appeals and stimulates employees would be better positioned in the competitive health-care industry and would demand quality and costefficient operations (Emem et al., 2014).

However, the dynamics of organisational work setting, especially in the health-care sector are that both non-clinical and clinical individuals would like to engage themselves in a hospital that offers suitable work environment, devoid of environmental threats to life and vulnerabilities, secured job and well-remunerated pay structure which by extension enhances job satisfaction (Jandaghi et al., 2011). Studies in the areas of organisational behaviour and organisational development have reported that the concept of job satisfaction is complicated because what constitutes job satisfaction to a set of employees may not apply to another set of employees and so it becomes a challenge to satisfy a group or a team of employees without carefully evaluating what makes individual satisfy (Bakotie and Babie, 2013; Choi et al., 2012; Malik, 2011). Therefore, employers need to understand what constitutes satisfaction for a different group of their workforce. Likewise, it has, also, been argued that firms cannot function at its peak unless employees are satisfied (Dixit and 
Bhati, 2012). Apart from customers, employees are the lifeblood of every business, and they are the major determinants of success or failure of every organisation (Bempah, 2013) . It has been observed that the extent to which health-care workers are satisfied with their jobs are in diverse techniques and this is susceptible to variables such as job environment, work hours and schedule, reward systems and the attitude of the management to employees (Osibanjo et al., 2014). In satisfying the workforce in the health-care industry, many factors interact to drive productive worker. One of the germane factors that propel employees in the health-care industry is the work climate otherwise called work environment (Ebuehi and Campbell, 2011).

A work environment is described as both the physical and emotional aspect surroundings of the workplace that drive commitment, productivity and employees' satisfaction. A conducive work environment plays a vital role in stimulating employees' job satisfaction, especially in the health-care industry which is plagued with incessant strike actions because of the poor work environment. Such a physical and emotional surrounding defines the working conditions, employee rights, employee voice, safe conditions of work, cooperative team members and friendly supervisor among others (Akinwale, 2019). It comprises two larger spectrums: work and context. Work consists of all the features of jobs and task activities such as training, autonomy, sense of accomplishment on the job, a variety of tasks and internal value for tasks. The other dimension of work environment and employees' satisfaction is context. It consists of the physical working atmosphere and the social working conditions (Baah and Amoako, 2011). In the broad view of Edem et al. (2017), work environment entails employees' safety, job security, good working relationship among employees, recognition for best effort and performance, greatly inspired for performing well and effective involvement in decision-making processes of the organisation. Adegoke et al. (2015) established that the moment employees understand that their organisation places a high priority on them, they would likely exhibit a greater level of dedication and sense of ownership in the workplace. Diverse elements associated within a working environment such as wages, working hours, employee independence, organisational structure and effective communication between management and its workforce may positively impact on employees' satisfaction (Lane et al., 2010). Another core factor of the work environment that provokes satisfaction in the workplace is a positive supervisory predisposition. Study of Maulabakhsh and Raziq (2015) has established that positive supervisory orientation not only fosters and nurtures talent development while keeping workers on the right track but could also exhibit conflict management ability that keeps the team to work favourably.

It is against this backdrop of performance indices of employees that this study investigates the impact of work environment on the level of job satisfaction of nurses in the Nigerian public health-care sector, particularly, in federal and state government tertiary hospitals in Lagos State. Thus, this study is established on the following objectives:

- To investigate the impact of socio-political climate, administrative and managerial support, autonomy and responsibility and salary on job satisfaction of nurses in government hospitals in Lagos State.

- To examine the impact of socio-political climate, administrative and managerial support, autonomy and responsibility, salary and supervision and working condition on job satisfaction of nurses in government hospitals in Lagos State.

- To analyse the significance of socio-political climate, administrative and managerial support, autonomy and responsibility, salary, supervision and working condition, and recognition and achievement on job satisfaction of nurses in government hospitals in Lagos State. 
RAMJ

14,1

- To demonstrate the effect of socio-political climate, administrative and managerial support, autonomy and responsibility, salary, supervision and working condition, recognition and achievement, advancement and promotion on job satisfaction of nurses in government hospitals in Lagos State.

To achieve the set objectives of this study, these four hypotheses given below were postulated and tested:

H1: Socio-political climate, administrative and managerial support, autonomy and responsibility and salary have an impact on the job satisfaction of nurses in government hospitals in Lagos State.

H2: Socio-political climate, administrative and managerial support, autonomy and responsibility, salary and supervision and working condition have an impact on job satisfaction of nurses in government hospitals in Lagos State.

H3: Socio-political climate, administrative and managerial support, autonomy and responsibility, salary, supervision and working condition and recognition and achievement have additional significance on the job satisfaction of nurses in government hospitals in Lagos State.

H4: Socio-political climate, administrative and managerial support, autonomy and responsibility, salary, supervision and working condition, recognition and achievement, advancement and promotion have a significant effect on the job satisfaction of nurses in government hospitals in Lagos State.

The significance of this paper is numerous. First, it unearths the understanding of the nurses about their work climate; second, it places emphasis on the variables of work environment in order of hierarchy and how it is central to the nurses in hospitals and, finally, it offers stakeholders in the health-care industry ample chance on how to drive and provoke health-care workers' productivity in the society.

\section{Review of literature}

Considering an individual to be healthy is described as a position of absolute physical, mental and social well-being and not just the absence of illness, sickness or disease (Eme et al., 2014). While the health-care industry represents an aspect of the largest employment creations globally (Ghaffari et al., 2017), a World Health Organisation report states that health-care service providers across the world hire about 60 million employees who are exposed to an array of difficult health and safety vulnerabilities, ranging from natural and organic vulnerabilities to unfavourable safety in the workplace and psychosocial attributes (Serdar et al., 2013). In many nations of the world, the paucity of health-care employees, presently and in the future, is a concern for stakeholders in the society. For emerging countries or developing nations, this may provoke migration and brain drain when highly qualified employees move to foreign nations, which may not be unrelated to work environment and job satisfaction. The satisfaction of health-care workers is seriously affected, especially in developing countries, which is the major justification for turnover intention to foreign countries where they will be appreciated and provided with better working conditions (Kovnet et al., 2014). The concept of the work environment and job satisfaction in the health-care sector has become a challenging debate owing to the issues and risks surrounding the profession globally. Majority of the workers are exposed to great hazards, as patients seeking good health condition have an interface with Nurses and 
Doctors in hospitals and so they are encountering difficulty in the profession in the course of interacting with patients seeking balance in their health systems. Thus, the safety and satisfaction of these health-care workers should be prioritised. Passion is a driving force that provokes satisfaction for Nurses in the health-care industry. Majority of the Nurses seek other better places, especially private hospitals when their aspirations and demands cannot be met. When they do not feel fulfilled on the job, satisfaction becomes difficult, likewise commitment to the objectives and goals of the hospitals will not be realised. Studies that focused on the job satisfaction of nurses and the determination to remain in their present employment in tertiary and government hospitals and clinics are abound (Heponiemi et al., 2011; Labarda, 2011).

In a recent study of Blomberg and Welander (2019), they affirmed that nurses who find happiness and derive satisfaction in their work would have embarked on several years of service in building such satisfaction and passion that drive them to productive work behaviour. In other words, happiness at work does not come once but accumulated with time consequent upon motivational techniques offered in the workplace. However, the turnover of nurses and other health-care workers, in general, can be expensive for the management of health-care organisations owing to engagement, training and retraining of employee (Lorber and Savic, 2012). Therefore, some of the health-care service providers motivate their health workers and ensure that they are happy and comfortable with their work and the surroundings of the organisation.

In relation to employee engagement with hospitals and the choice of where to work, job satisfaction is one of the essentials and, most the time, determines employees' intention to stay in their present position (Edoho et al., 2015). Considerations such as salary, limited autonomy and stressed pattern of work lead to poor job satisfaction (Goetz et al., 2015). Existing literature has demonstrated that nurse with a high degree of job satisfaction would be highly innovative and be driven to improve the organisation, which would be appropriate for patients/attendees to access (Goetz et al., 2011; Van der Doef et al., 2012). Happy nurses are prone to be hardworking, motivated and committed to their work.

Studies have established the association between the work environment and job satisfaction across diverse contextual premises (Aiken et al., 2013; Chaudhury, 2015; Kim, 2015; Khunou and Davhana-Maselesele, 2016). The idea of the work environment and job satisfaction is receiving increasing significance with time owing to its influence on the larger society. The outcomes of the Danish study implies that an organisation can enhance its work productivity via the improved physical attributes of the work environment, and internal climate, which may have a positive effect on organisational productivity (Maulabakhsh and Raziq, 2015). Sell and Cleal (2011) advanced a model on employee satisfaction by adding financial elements and work environment factors to discover the response of workers in a precarious work environment with high monetary gains, safe work environment and low financial rewards. The report of the study indicates that diverse psychosocial and work climate factors such as workplace condition and social support have an immediate effect on employee satisfaction, as increase in reward benefits failed to enhance poor satisfaction among workers.

The crucial effect of health-care staff job satisfaction on patient care, the satisfaction of the patient, the quick attention to patient and overall quality of health-care service delivery cannot be overemphasised. This is as a result of putting in place a good work environment. Despite the fundamental attention that organisational behaviour and human resource issues received in recent times, health-care staff in developing countries owned-up that their supervisors and superiors were not concerned about their satisfaction and work environment. It was established that responsibility, recognition and training were the main 
RAMJ

14,1

factors that drive nurses to be dedicated in developing nations, yet those factors are not available (Oyetunde and Ayeni, 2014). So many factors positively and negatively affect the job satisfaction of nurses in developing countries. Poor and abusive supervision, poor social camaraderie among the employees, low incentives and reward system, policy, task overload, growth and promotion and working condition all have been reported to positively impact nurse high job satisfaction (Oyeleye et al., 2013), but lack of those factors have indicated low or no satisfaction which has an overbearing effect on patients' outcome (Arsalani et al., 2012).

Another complex factor that hinders nurses' satisfaction is a poor working condition which results in "stressors". This ranges from poor communication to medication errors and increased patient mortality (Murta et al., 2011). In asymmetric to various studies explaining health-care staff job stressors, there are negated potential interventions directed and designed at stimulating health-care employees working condition in hopsitals (Lunenburg, 2011). Meanwhile, working conditions are alerts and reactive to nurturing and improving the system, more importantly, to change the work organisation (Wallace et al., 2012). Hospital management re-design for quality health-care staff is advocated as a sustainable means of reducing job stressors, improve job control and provoke a safety environment for patients (Arnetz, 2011).

\subsection{Theoretical review}

2.1.1 Job design theory. The underpinning theory for this study is the theory of job design which has direct bearing with job satisfaction, workplace productivity and work climate improvement. Job design is a psychosomatic theory of drive that describes the systematic and purposeful distribution of job task to the team, group and individuals in an organisational setting. The five components of job design are skill variety, task identity, task significance, autonomy and job feedback (Stringer et al., 2011). All of these stimulate employees' commitment and job satisfaction. The theory involves a combination of job content and work method which has been embraced in the performance of the work (De Cooman et al., 2013). The first proponent of job design theory was Viteles in the early 1950s and later was further developed by Hackman and Oldham (1980). The theory has several other strategies for enhancing employee performance. The major strategies are job rotation, job enlargement, job enrichment, self-managing teams, otherwise called an autonomous workgroup, and high-performance work design. Other techniques include job reengineering, participative management and performance review (Halepota and Shah, 2011). This theory utilises both job rotation and job enlargement to deal with the issues bothering poor employee morale and performance because of the monotony and boredom from job specification (Nahrgang et al., 2011). Besides, job rotation and job enlargement were established such that it will be of benefit to job specialisation evolving from job engineering technique (Parker et al., 2017).

This theory is of the view that two factors come into being in provoking employees' satisfaction and by extension the ultimate quality performance in the workplace. One of it is the fact that job design seeks to integrate means in which change to job characteristics, such as workload, autonomy, variety and workplace supervisory support (Tement and Korunka, 2013), will lead to enhanced worker's satisfaction and hence increased performance (Van den Broeck et al., 2013). The second aspect is the benefits of job design, which are improved job satisfaction, inner drive of the workforce, (Marinova et al., 2015) and increased employees' skills and ability (Oldham and Hackman, 2010). Indeed, job design is appropriate to explain employee satisfaction and commitment in the work setting, as it has a direct relationship with improved workers' productivity (Parker, 2014). 
Job design theory, in addition, largely offers that there are set of opportunities and constraints considered into tasks distribution and role functions that affect how employees fulfils their job functions (Hackman and Oldham, 1980). Thus, in job design theory, organisational leaders and superiors should understand factors of job characteristics that will make their workforce happy and satisfied with their work to realise productive work behaviour (Baker et al., 2010). This further explains the model in Figure 1 below.

However, in job design as evidence in the model above, the job characteristics and connection between a component of job and employee reactions to work is crucial to goal accomplishment of the health-care management as well as job satisfaction of the health-care employees. It advances conditions that employee will likely perform very well on the job (Hackman and Oldham, 1976). Therefore, Hackman and Oldham (1980) propose five dimensions of job design that impact on a psychological position that gears peculiar benefits to individual and job outcomes. It takes into consideration employee divergent views as moderating factor of association between job features and job outcome factors. Therefore, Hackman and Oldham (1980) establish the five job characteristics as follows:

- Skill variety: This explains the extent to which a job demands various skills, ability and capacity from an individual employee in achieving a set task. This is said to drive employee satisfaction when an employee has the necessary skills to perform a certain task and opportunity for training where there is a deficiency of required skills.

- Task identity: It describes the aspect in which job demands realising complete and identifying the part of the job task that will help in accomplishing the work from beginning to the end with a visible, marked and positive outcome. This also is said to motivate employee and gear them to be happy on the job.

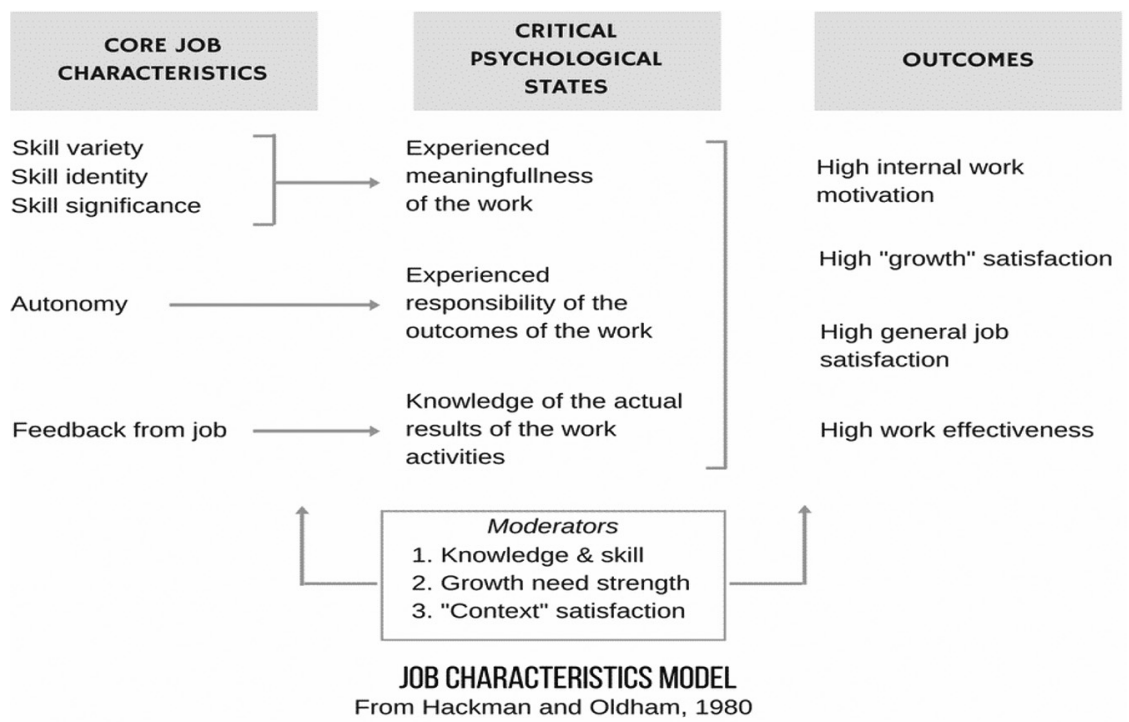

Source: Hackman and Oldman, (1980, p. 90)

Figure 1. Job characteristics model 
RAMJ

14,1

\section{8}

- Task significance: This emphasises the extent to which a job has a cogent influence on the well-being of other employees, or how it affects other employees, within and outside the firm. In other words, employees' understanding of several other individuals who depend on the work they are performing is a crucial point in their satisfaction.

- Job autonomy: This describes the degree of independent judgement to make informed decision and discretion regarding the assigned task given to individual employees. In other words, the liberty to expand on the job and responsibilities is given to the employees to perform their duties and functions effectively. Autonomy in the workplace provides employees with a sense of job ownership and make them feel in charge of the work which largely steers up the satisfaction in an individual employee

- Job feedback: It explains a process by which reporting managers, superiors and peers at work offer constructive suggestions to employees on the assigned task which allows improvement and possible enhanced productive work behaviour (Chen and $\mathrm{Lu}, 2012$ ). This, according to the theorist, stimulates dedication of employees and make them happy on the job.

Nevertheless, the critics of this theory (Van den Broeck et al., 2015; Luenendonk, 2017; Taber and Taylor, 1990) have pointed out that Hackman and Oldhman's theory failed to take cognisance of other perceived objective job characteristics relationship. The proposition left the importance of suggestions from other individuals who are incumbent of such job position that may improve perceived task features. At the same time, the social clues which may offer a positive impact on identified job features could be more fundamental for redesigning job task. They argued further that not only unbiased or controlling job enrichment has a positive impact on satisfying individual employee but also social clues needed to be included in the job design elements.

Another school of thought that criticised this theory argued that job design only empahsised on the presence of narrow set of job characteristics, intervening variables (mederators) and behavioural results. That the model was only directed at motivational techniques at work but neglect the stressful aspect of work that this may create (Parker et al., 2011). These scholars, thus, suggested an all-encompassing dimension of job characteristics model will establish an extended system of job characteristics, which include those more fundamental in the modern-day workplace, such as emotional and performance monitoring demands, and operational uncertainty and outcomes such as creativity, proactivity and safety at work.

\section{Research methods}

\subsection{Research design}

This paper investigates the impact of work environment on job satisfaction among nurses in University tertiary hospitals in Lagos State. It utilised a longitudinal research design to survey the nurses in tertiary hospitals in Lagos State, Nigeria. The study surveys the participants on a three months interval basis repeatedly for nine months. The choice of longitudinal is that it helps to describe the patterns of variation and offers the direction and degree of a causal association. Also, it allows measurements on each variable of the study over three distinct periods to be taken in order to understand the change in the initial response obtained. It helps to assess the pervasiveness of a phenomenon which is job satisfaction in this study. It assists in measuring multiple variables in the population of interest at a particular moment (Bryman, 2012). 
The population of this study is Nurses in tertiary hospitals in Lagos State. The hospitals under study are University of Lagos Health Centre, Lagos University Teaching hospital (LUTH), Lagos State University Teaching Hospital (LASUTH). The population of registered nurses therein are 33 nurses in University of Lagos health centre, 815 in LUTH and 1,215 in LASUTH. The total figure of the nurses in both federal and state government tertiary hospitals therefore amounts to 2,063. Nurses registered, trained and licensed by the Nursing and Midwifery Council of Nigeria and whose working experience span through 9-12 months form the basis of the sample eligibility and inclusion for this study. Participants were taken from various units/departments of the hospitals. The sample size is determined through a statistical measure of sample size determination approach of Yamane (1967)

$$
\mathrm{n}=\frac{\mathrm{N}}{1+\mathrm{N}(\mathrm{e})^{2}}
$$

Where $n=$ sample size, $\mathrm{N}=$ population size, $\mathrm{e}=$ error term at 0.05

$$
\mathrm{n}=\frac{2063}{1+2063(0.05)^{2}}
$$

which gives 335. However, to provide for non-response of the respondents and unforeseen circumstances, the sample was increased by $20 \%$ and the total sample size got up to 402.

\subsection{Sampling technique}

In selecting the participants for this study, the simple random sampling strategy was adopted. The use of simple random is justified as it enables the entire population to be represented with an equal opportunity of being taken. Also, it takes away the difficulty of being biased and prevents the preferential nature of the researchers for a particular set of participants to be included (Babbie, 2013).

\subsection{Research instrument}

The research instrument for this study is a research questionnaire scale nursing work index (NWI) originally developed by Kramer and Hafner (1989) and later revised by Aiken and Patrician (2000). It adapts the Revised Nursing Work Index (NWI-R) questionnaire developed by Aiken and Patrician (2000) for collecting data from the respondents as well. The scale consists of 57 items of nursing work index (NWI-R), 6 items related to job satisfaction and nurse-assessed quality of care. The scale used five-point Likert-scale response. The nurses' job satisfaction was measured in seven variables, including the items on opportunity for growth, promotion and advancement, policy and administration, responsibility, salary, supervision and overall working condition, recognition and achievement and socio-political climate. The five-point Likert scale ranges from very dissatisfied, somewhat dissatisfied, fair, somewhat satisfied and very satisfied.

\subsection{Validity and reliability of the research instrument}

In the bid to increase the external validity, instructions were supplied alongside sociodemographic variables of the respondents which were not added in the initial NWI-R questionnaire. Content validity relied on the fact that the instrument employed was created on the existing literature and tools of Aiken and Patrician (2000), and nurses' working 
RAMJ

14,1

condition structure. NWI-R has been noted by studies to produce high reliability, validity (face, content and criterion-associated) and internal consistency in scoring as indicated by Cronbach's alpha scores (Slater et al., 2010; Vahey et al., 2004). To evaluate internal consistency, Cronbach's alpha values were calculated for the data. The general reliability coefficient is 0.86 . The NWI-R covers 57 items regarding characteristics of the nursing working environment. A total of 15 NWI-R items were classified into subscales called autonomy and responsibility with Cronbach's alpha value of (0.78); 10 of these subscales were grouped in a subscale called administrative and managerial support with Cronbach's alpha of (0.79); opportunity for advancement and promotion takes Cronbach's alpha of (0.75); recognition and achievement has Cronbach's alpha of (0.71); supervision and working condition has alpha of (0.77); salary takes alpha value of (0.72); and socio-political climate has Cronbach's alpha value of (0.73).

3.5.1 Ethical consideration. The researchers follow informed consent seeking for opinion of participants before administering the questionnaire on the study population. The study, however, has considered five dimensions of ethical dilemma in line with Cash et al. (2009) when conducting a scientific study. These guidelines focus on voluntary participation from respondents, no harm to respondents, anonymity and confidentiality, identifying purpose and sponsor. In line with these, the researchers ensure that the study did not create any harm to the study population and sought participation willingly

\subsection{Data analysis technique}

The analytic technique employed for this study is the hierarchical regression model. Hierarchical regression is a statistical strategy of evaluating the relationships that exist among variables of interest and measure hypotheses about a dependent variable and several independent variables together. The essence of this analytic tool is that it helps to demonstrate if variables of interest elucidate a statistically optimistic amount of variability in the dependent variable after explaining all other variables. Another justification for using this model is that the observations of this study fall into hierarchical steps and the researcher wanted to investigate if some set of variables account for additional variability and significance in the study, as the study investigated seven variables in sequential and hierarchical order.

Thus, in determining how much variability in nurses' job satisfaction is explained by components of the work environment, a four-stage hierarchical multiple regression using enter method was deemed an appropriate technique of analysis (Darren and Paul, 2012). However, suitable and pertinent assumptions of this statistical analysis were observed and ensured the study take cognizance of it. From the tests conducted, the data fulfilled the assumptions for no multicollinearity (Coakes, 2005) and no independent errors (DurbinWatson $=2.02$ ). Further analysis of standard residuals established that the data found no outliers (Std. Residual Min $=-1.57$ Std. Residual Max $=2.58$ ), and scatter plots confirmed the assumptions of linearity and homogeneity were all fulfilled (Hair et al., 2014). As all the assumptions were fulfilled, the hierarchical multiple regression analysis $\left(R^{2}\right)$ started, through a fixed order of entry the degree to which the predictor variables predicted the criterion variable was determined.

\section{Results of descriptive analysis}

Table 1 indicate the demographic status of the respondents ranging from gender, age educational background designation of the nurses surveyed, their professional experience, the department they work with, monthly income and their marital profile. A total valid of 365 copies of the questionnaire were analysed out of 402 administered 


\begin{tabular}{|c|c|c|c|}
\hline Profile & Frequency & $(\%)(n=365)$ & satisfaction \\
\hline $\begin{array}{l}\text { Gender } \\
\text { Male } \\
\text { Female }\end{array}$ & $\begin{array}{r}65 \\
300\end{array}$ & $\begin{array}{l}17.8 \\
82.2\end{array}$ & among nurses \\
\hline $\begin{array}{l}\text { Age } \\
22-30 \\
31-39 \\
40-48 \\
49-57 \\
58-65\end{array}$ & $\begin{array}{r}63 \\
85 \\
105 \\
62 \\
50\end{array}$ & $\begin{array}{l}17.3 \\
23.3 \\
28.8 \\
16.9 \\
13.7\end{array}$ & 81 \\
\hline $\begin{array}{l}\text { Education } \\
\text { Diploma (RN/RM) } \\
\text { Post basic diploma } \\
\text { BSc Nursing } \\
\text { Postgraduate diploma } \\
\text { Master's degree }\end{array}$ & $\begin{array}{r}45 \\
55 \\
150 \\
65 \\
50\end{array}$ & $\begin{array}{l}12.3 \\
15.1 \\
41.1 \\
17.8 \\
13.7\end{array}$ & \\
\hline $\begin{array}{l}\text { Designation } \\
\text { Nursing Officer II } \\
\text { Nursing Officer I } \\
\text { Senior nursing officer } \\
\text { Principal nursing officer } \\
\text { Assistant chief nursing } \\
\text { Chief nursing officer } \\
\text { Assistant director of nursing } \\
\text { Service (ADNS) }\end{array}$ & $\begin{array}{r}88 \\
125 \\
85 \\
35 \\
20 \\
7 \\
5\end{array}$ & $\begin{array}{r}24.1 \\
34.3 \\
23.3 \\
9.6 \\
5.5 \\
1.9 \\
1.3\end{array}$ & \\
\hline $\begin{array}{l}\text { Department } \\
\text { Anaesthesia } \\
\text { Community health and primary care } \\
\text { Dietetics } \\
\text { Dentistry } \\
\text { Family medicine } \\
\text { Paediatrics } \\
\text { Intensive care } \\
\text { Accident and emergency unit } \\
\text { Obstetrics and gynaecology }\end{array}$ & $\begin{array}{l}35 \\
85 \\
25 \\
20 \\
65 \\
85 \\
10 \\
30 \\
10\end{array}$ & $\begin{array}{r}9.6 \\
23.3 \\
6.8 \\
5.5 \\
17.8 \\
23.3 \\
2.7 \\
8.3 \\
2.7\end{array}$ & \\
\hline $\begin{array}{l}\text { Nursing professional experience } \\
1-10 \\
11-20 \\
21-30 \\
31-35 \\
\text { Above } 35\end{array}$ & $\begin{array}{r}82 \\
120 \\
127 \\
25 \\
11\end{array}$ & $\begin{array}{r}22.5 \\
32.9 \\
34.8 \\
6.8 \\
3.0\end{array}$ & \\
\hline $\begin{array}{l}\text { Monthly income (Thousand Naira) } \\
100-150 \\
200-250 \\
300-350 \\
400-450 \\
500-550 \\
600-\text { above }\end{array}$ & $\begin{array}{l}70 \\
60 \\
95 \\
85 \\
30 \\
25\end{array}$ & $\begin{array}{c}19.2 \\
16.4 \\
26.0 \\
23.3 \\
8.3 \\
6.8 \\
\text { (continued) }\end{array}$ & $\begin{array}{r}\text { Table 1. } \\
\text { Demographic profile } \\
\text { of the nurses in } \\
\text { tertiary hospitals }\end{array}$ \\
\hline
\end{tabular}


RAMJ

14,1

questionnaires to the tertiary hospitals in Lagos. The participants' sex profile depicts that $65(17.8 \%)$ of the total participants were male nurses while $300(82.2 \%)$ were female nurses. The implication of this is that, the nursing profession has generally been a career for women albinitio; onlya few men are eager to venture. The age of the respondents ranges from 22 to 65 years with a mean age of $51 \pm 15.78$ and a modal group of 40-48 years. Majority of the respondents were married as 210 (57.5\%), 110 $(30.1 \%)$ of them were single, $25(6.9 \%)$ were divorced while $20(5.5 \%)$ of the respondents were widows. On the educational background of the respondents, $45(12,3 \%)$ were diploma registered nurses and midwives, $55(15.1 \%)$ were holders of Post-basic Diploma, $150(41.1 \%)$ were holders of BSc. Nursing, 65 (17.8\%) were Postgraduate Diploma in Nursing and 50(13.7\%) were Master of Science in Nursing or Master of Public Health degree holders. This shows that they were all informed and registered, and qualified with the Nigerian Council of Licensed Nursing. Regarding the designation of nurses in the tertiary hospitals, $88(24.1 \%)$ of them were on category of Nursing Officer II, $125(34.3 \%)$ were on classification of Nursing Officer I, while $85(23.3 \%)$ were Senior Nursing Officer, 35 (9.6\%) of them were on the level of Principal Nursing Officer, $20(5.5 \%)$ was Assistant Chief Nursing, while 7(1.9\%) and $5(1.3 \%)$ were Chief Nursing Officer and Assistant Director of Nursing Service (ADNS), respectively. Concerning the professional years of experience, $82(22.5 \%)$ had 1-10 years of work experience, 120 $(32.9 \%)$ were on $11-20$ years of experience category, $127(34.8 \%)$ had $21-30$ years of professional working experience. $25(6.8 \%)$ were on the category of 31-35 years of work experience, while $11(3 \%)$ were above 35 years. Majority of the respondents were in Community Health and Primary Care with $85(23.3 \%)$ as well as in Paediatrics Department, Family Medicine Unit recorded 65 (17.8\%) of the respondents, $35(9.6 \%)$ were from Anaesthesia Department with the peri-operative session. 25 (6.8\%) and 20 $(5.5 \%)$ were from the Dietetics and Dentistry Department, respectively. $30(8.3 \%)$ were from Accident and Emergency Unit of the tertiary hospitals in Lagos State, while 10 $(2.7 \%)$ were from Intensive Care and Obstetrics. Last, in Table 1 is the monthly income of the nurses, the majority of the respondents, $95(26 \%)$ were on the salary scale of $\mathrm{N} 400,000$ to $\mathrm{N} 450,000$ thousand per month. While relatively higher, $85(23.3 \%)$ were on the salary scale of N300,000 to N350,000 thousand per month, $70(19.2 \%)$ and $60(16.4 \%)$ were on, respectively, salary measure of N100,000 to N150,000 thousand and N200,000 to N250,000 thousand on monthly basis. Also 30 (8.3\%) and $25(6.8 \%)$ were on N500,000 to N550,000 thousand and N600,000 above salary structure per month, respectively. The implication of this is that in government hospitals, health-care workers are relatively paid well which means that salary may not be challenging to them but other factors. Given the descriptive analysis of the monthly income, it shows that they were

\begin{tabular}{lcc}
\hline Profile & Frequency & $(\%)(n=365)$ \\
\hline Marital status & & \\
Single & 110 & 30.1 \\
Married & 210 & 57.5 \\
Divorce & 25 & 6.9 \\
Widow & 20 & 5.5 \\
Source: Field Survey, 2019 & & \\
\hline
\end{tabular}

Table 1.

Source: Field Survey, 2019 
fantastically paid, and this may be a form of job satisfaction as Nigerian socio-economic environment is concerned.

\section{Job satisfaction among nurses}

\subsection{Data analysis and results}

Table 2 is an indication of the model summary of hierarchical multiple regression analysis, predictors of job satisfaction among nurses in tertiary hospitals in Lagos State, Nigeria. A four-stage hierarchical multiple regression analysis was carried out to investigate the connection between the set of independent variables (socio-political climate, administrative and management support, autonomy and responsibility, salary, supervision and working condition, recognition and achievement and advancement and promotion), against the dependent variable (job satisfaction). Model 1 depicts that the socio-political climate, administrative and managerial support, autonomy and responsibility and salary have an Rvalue of 0.698 which means that $69.8 \%$ strength of relationship exists among the dependent variables and nurses' job satisfaction in tertiary hospitals in Nigeria. A positive relationship occurs between socio-political climate, administrative and managerial support, autonomy and responsibility, salary, and nurses' job satisfaction. The $R^{2}(0.487$ or $48.7 \%)$ provides variability that accounts for nurses' job satisfaction in Model 1 . Also, $R^{2}$ change offers $48.7 \%$ which depicts variance in nurses' job satisfaction. The hierarchical multiple regression reveals that at stage one, socio-political climate, administrative and managerial support, autonomy and responsibility, and salary contributed significantly to the regression model, $F(4,360)=85.275, p<0.05$. The relationship between variable was robust. Significant $F$-change also reveals that the model is significant given the value of at $p=0.00$.

\begin{tabular}{|c|c|c|c|c|c|c|}
\hline Model & $\mathrm{R}$ & $R^{2}$ & Adjusted $R^{2}$ & $R^{2}$ Change & $F$-change & Sig. \\
\hline 1 & 0.698 & 0.487 & 0.481 & 0.487 & 85.275 & 0.000 \\
\hline 2. & 0.698 & 0.487 & 0.479 & 0.000 & 0.080 & 0.135 \\
\hline 3. & 0.700 & 0.490 & 0.481 & 0.003 & 2.240 & 0.029 \\
\hline 4. & 0.705 & 0.497 & 0.487 & 0.276 & 4.821 & 0.000 \\
\hline \multicolumn{7}{|c|}{ ANOVA } \\
\hline & Model & Sum of squares & $d f$ & Mean square & $F$ & Sig. \\
\hline \multirow[t]{3}{*}{1.} & Regression & 65.626 & 4 & 16.406 & \multirow[t]{3}{*}{85.275} & \multirow[t]{3}{*}{0.000} \\
\hline & Residual & 69.262 & 360 & 0.192 & & \\
\hline & Total & 134.888 & 364 & & & \\
\hline \multirow[t]{3}{*}{2.} & Regression & 65.641 & 5 & 13.128 & \multirow[t]{3}{*}{68.061} & \multirow[t]{3}{*}{0.000} \\
\hline & Residual & 69.247 & 359 & 0.193 & & \\
\hline & Total & 134.888 & 364 & & & \\
\hline \multirow[t]{3}{*}{3.} & Regression & 66.072 & 6 & 11.012 & \multirow[t]{3}{*}{57.287} & \multirow[t]{3}{*}{0.000} \\
\hline & Residual & 68.816 & 358 & 0.192 & & \\
\hline & Total & 134.888 & 365 & & & \\
\hline \multirow[t]{3}{*}{4.} & Regression & 66.989 & 7 & 9.570 & \multirow[t]{3}{*}{50.316} & \multirow[t]{3}{*}{0.000} \\
\hline & Residual & 67.899 & 357 & 0.190 & & \\
\hline & Total & 134.888 & 364 & & & \\
\hline
\end{tabular}

Notes: ${ }^{a}$ Dependent variable: job satisfaction $(\mathrm{P}<0.05){ }^{\mathrm{b}}$ Predictors (constant), salary, administrative and

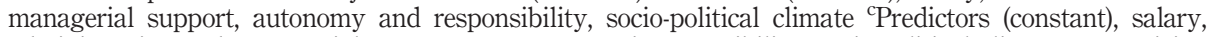
administrative and managerial support, autonomy and responsibility, socio-political climate, supervision and working condition ${ }^{\mathrm{d}}$ Predictors (constant), salary, administrative and managerial support, autonomy and responsibility, socio-political climate, supervision and working condition, recognition and achievement ePredictors (constant), salary, administrative and managerial support, autonomy and responsibility, sociopolitical climate, supervision and working condition, recognition and achievement, advancement

Table 2.

Model summary of hierarchical regression analysis 
RAMJ

14,1

84

Table 3.

Summary of hierarchical regression analysis of seven predicting variables on job satisfaction
However, looking at the individual contribution of the variables against job satisfaction in table 4 reveals that all the first three variables of the first model were not individually significant except salary which had a significant impact on job satisfaction only thus: $\beta=$ $0.323, t=4.060, p=0.000$ highly significant. Given this result, it can be seen that salary is a key element in making nurses happy in a tertiary hospital in Lagos as other variables were not significantly impacting on job satisfaction on an individual basis except collectively. Socio-political climate values ( $\beta=0.244, t=1.999, p=0.046$ ), administrative and managerial support $(\beta=-0.113, t=1.196, p=0.233)$ not significant; autonomy and responsibility ( $\beta=$ $-0.032, t=-0.352, p=0.725)$ not significant. In conclusion, the first model collectively shows a significant impact on nurses' job satisfaction in tertiary hospitals in Lagos State; hence, there is enough justification to reject the $H 1$ and accept that:

H1. Socio-political climate, administrative and managerial support, autonomy and responsibility, and salary have impact on the job satisfaction of Nurses in government hospitals in Lagos State.

Adding Stage 2 to the regression model from Tables 3 accounted for no additional value, same $\mathrm{R}=69.8 \%$ and $R^{2}=47.9 \%$ variations which accounted for job satisfaction. The $R^{2}$ change $(0.00)$ also has no additional value but the change in $R^{2}$ was significant,

\begin{tabular}{|c|c|c|c|c|c|}
\hline Variables & B. & SE (std. error) & Beta & $\mathrm{T}$. & Sig. \\
\hline \multicolumn{6}{|l|}{ Stage 1.} \\
\hline Socio-political climate & 0.301 & 0.150 & 0.244 & 1.999 & 0.046 \\
\hline Administrative and management support & 0.137 & 0.114 & 0.113 & 1.196 & 0.233 \\
\hline Autonomy and responsibility & -0.038 & 0.107 & -0.032 & -0.352 & 0.725 \\
\hline Salary & 0.454 & 0.112 & 0.323 & 4.060 & 0.000 \\
\hline \multicolumn{6}{|l|}{ Stage 2.} \\
\hline Socio-political climate & 0.296 & 0.152 & 0.240 & 1.948 & 0.052 \\
\hline Administrative and management support & 0.136 & 0.114 & 0.113 & 1.192 & 0.234 \\
\hline Autonomy and responsibility & -0.034 & 0.108 & -0.028 & -0.313 & 0.755 \\
\hline Salary & 0.454 & 0.112 & 0.393 & 4.064 & 0.000 \\
\hline Supervision and working condition & -0.011 & 0.038 & -0.011 & -0.283 & 0.777 \\
\hline \multicolumn{6}{|l|}{ Stage 3.} \\
\hline Socio-political climate & 0.294 & 0.152 & 0.238 & 1.940 & 0.053 \\
\hline Administrative and management support & 0.136 & 0.114 & -0.112 & 1.188 & 0.236 \\
\hline Autonomy and responsibility & -0.030 & 0.108 & -0.025 & -0.275 & 0.783 \\
\hline Salary & 0.451 & 0.112 & -0.390 & 4.042 & 0.000 \\
\hline Supervision and working condition & -0.037 & 0.042 & -0.037 & -0.883 & 0.378 \\
\hline Recognition and achievement & 0.063 & 0.042 & 0.062 & 1.497 & 0.135 \\
\hline \multicolumn{6}{|l|}{ Stage 4.} \\
\hline Socio-political climate & 0.280 & 0.151 & 0.227 & 1.858 & 0.064 \\
\hline Administrative and management support & 0.132 & 0.114 & 0.109 & 1.158 & 0.248 \\
\hline Autonomy and responsibility & -0.037 & 0.108 & -0.031 & -0.340 & 0.734 \\
\hline Salary & 0.472 & 0.111 & 0.408 & 4.232 & 0.000 \\
\hline Supervision and working condition & -0.030 & 0.042 & -0.031 & -0.726 & 0.468 \\
\hline Recognition and achievement & 0.039 & 0.043 & 0.039 & 0.916 & 0.360 \\
\hline Advancement and promotion & 0.000 & 0.036 & 0.085 & 2.196 & 0.029 \\
\hline
\end{tabular}


$F(5,359)=68.061, p=0.000$ and the relationship between these variables shows a robust association at $\mathrm{R}=69.8 \%$. However, of the five variables only salary was a significant predictor of nurses' job satisfaction $(\beta=0.393, t=4.064, p=0.000)$, while other remaining variables were not impacting on Nurses' job satisfaction. Socio-political climate $(\beta=0.240, t=1.948, p=0.052)$ not significant, administrative and managerial support ( $\beta=0.113, t=1.192, p=0.234$ ) not significant; autonomy and responsibility $(\beta=-0.028, t=-0.313, p=0.755)$ not significant; and supervision and working condition $(\beta=-0.011, t=-0.283, p=0.777)$ not significant. Therefore, the most significant predictor of nurses' job satisfaction is salary. Together, the five predictor variables accounted for $47.9 \%$ of the variance in nurses' job satisfaction. Hence, there is rationale accept $H 2$ of this study that

H2. Socio-political climate, policy and administrative and managerial support, autonomy and responsibility, salary, and supervision and working condition have significant impact on job satisfaction of Nurses in tertiary government hospitals in Lagos State.

Taking a look at Stage 3 of the hierarchical regression model thus, accounted for additional $49 \%\left(R^{2}\right.$ change $\left.=0.3 \%\right)$ of variation in Nurses' job satisfaction in government tertiary hospitals and this change in R-square was significant, $\mathrm{F}(6,358)=57.287, p=$ 0.000 . The strength of the relationship among these six variables against job satisfaction shows a strong connection at $70 \%$. However, salary remains, the most significantly impacting predictor of nurses' job satisfaction $(\beta=-0.390, t=4.042, p=0.000)$ highly significant; socio-political climate $(\beta=0.238, t=1.940, p=0.053)$ not significant; administrative and managerial support $(\beta=-0.112, t=1.188, p=0.236)$ not significant; autonomy and responsibility $(\beta=-0.025, t=-0.275, p=0.783)$ not significant; while supervision and working condition $=(\beta=-0.037, t=-0.883, p=0.378)$ not significant; and recognition and achievement $=(\beta=0.062, t=1.497, p=0.135)$ not significant. Yet, the most significant determinant of nurses' job satisfaction was salary. Collectively, the six predictor variables accounted for $49 \%$ variability in nurses' job satisfaction which means that other factors that could explain satisfaction in nurses' work environment lies outside these six evaluated variables. Therefore, given the results of Stage 3, there is evidence to accept $H 3$.

H3. Sociopolitical climate, administrative and managerial support, autonomy and responsibility, salary, supervision and working condition, and recognition and achievement have additional significance on the job satisfaction of Nurses in government hospitals in Lagos State.

Stage 4 of the hierarchical multiple regression model of this paper reveals a significant outcome and an additional impact on job satisfaction. Stage 4 has 7 predictor variables (socio-political climate, administrative and managerial support, autonomy and responsibility, salary, supervision and working condition, recognition and achievement, advancement and promotion) which increases the strength of relationship from $70 \%$ to $70.5 \%$, R-value $=70.5 \%$, with $R^{2}$ value of 0.497 . Therefore, $49.7 \%$, of the variation has accounted for in nurses' job satisfaction. The Rsquare change $\left(R^{2}\right)$ was also highly significant as $\mathrm{F}(7,357)=50.316, p=0.000$, and the relationship between all the seven variables against job satisfaction was highly strong at $70.5 \%$. However, of all seven predictor variables, only salary, advancement and promotion significantly impacted on nurses' job satisfaction, others were not when taken individually. Salary ( $\beta=0.408$, $t=4.232, p=0.00$ )- highly significant and a predictor of job satisfaction; advancement and 
RAMJ

14,1

promotion $(\beta=0.085, t=2.196, p=0.029)$ highly significant and is a predictor of job satisfaction. Other six predictor variables were not significant, socio-political climate $(\beta=0.227, t=1.858, p=$ 0.064 ) not significant; administrative and managerial support ( $\beta=0.109, t=1.158, p=0.248$ ) not significant; autonomy and responsibility $(\beta=-0.031, t=-0.340, p=0.734)$ not significant; supervision and working condition $(\beta=-0.031, t=-0.726, p=0.468)$ not significant; recognition and achievement $(\beta=0.039, t=1.916, p=0.360)$ not significant. Therefore, the two significant predictors of job satisfaction were Salary, and advancement and promotion. Thus, given the result of the analysis, there is evidence to accept $H 4$ :

H4. Socio-political climate, administrative and managerial support, autonomy and responsibility, salary, supervision and working condition, recognition and achievement, advancement and promotion have a significant effect on the job satisfaction of Nurses in government hospitals in Lagos State

\section{Discussion of findings}

This study has provided vital outcomes, as several studies (Bakotic and Babie, 2013; Chamal and Dilina, 2018; Chaudhury, 2015; Edem et al., 2017; Edoho et al., 2015), have linked the association between the identified variables of this study (salary, administrative and managerial support, autonomy and responsibility, socio-political climate, supervision and working condition, recognition and achievement, advancement and promotion) as predictor of job satisfaction among nurses in government hospitals across countries of the world. This study also takes the same position as those studies mentioned in the literature above. The predominant predictor of nurses' job satisfaction in sequential order was salary. The study revealed that salary was the basis of satisfaction among the nurses. However, this may not be unconnected with socio-economic realities in the country. A typical Nigerian who receives handsome pay/reward at work will be happy and exhibit positive behaviour both at work and in the social space. Therefore, money is essential in the daily life of an average Nigerian as the majority of the nurses are mothers who take up financial responsibilities that they needed to respond to. Thus, it seems the salary and reward system make nurses enjoy what they do every day and bond them with quality service delivery and rapid attention to patients. Another factor which is next to salary that appears at the last stage of the hierarchical model is advancement and promotion. The reason it takes pre-eminence as the determinant of nurses' job satisfaction is that the result of job promotion and growth by extension, ultimately comes with an increase in salary; and Nigerian Nurses appreciate money. However, all the variables provide satisfaction to nurses collectively but hierarchically few of the factors take superiority in provoking job satisfaction. Largely, all the postulated hypotheses were positively related to the job satisfaction of Nurses in government tertiary hospitals in Lagos State, Nigeria. It is obvious why salary, pay and reward systems attract the attention of nurses in Nigerian tertiary hospitals. The government, a few years ago, did upward review and increased the pay structure of healthcare workers in both federal and state tertiary hospitals in Lagos State in a bid to ensure quality service delivery to the citizenry in the state.

\section{Conclusion and recommendations}

Happiness at whatever an individual does in the workplace is fundamental to such an individual lifestyle. Same goes for nurses as their satisfaction positively impact on patients' safety, productive work behaviour, quality care and attention, turnover, dedication and engagement to work as well as to their profession. Nursing, like any other profession, has its 
hazards, especially in health-care delivery institutions where nurses regularly have an interface with patient being infected with diseases, toxic, dangerous and risky compounds, solutions and medications. Such circumstances make it vital for the management of healthcare institutions and government to provide a mechanism that will make the health-care workers satisfied at all times since they are vulnerable to contracting heinous diseases and sickness encountering in the course of their work. Therefore, to retain and prevent nurses, and other health-care workers' turnover intention and to discourage them from moving from one hospital to another especially away to foreign established hospitals, the work environment must be of concern to management of hospitals as this will likely increase health-care system effectiveness, boost mental and social health of the nurses in the state and the entire country at large. Given this background, this study makes the following recommendations in other to improve on the recent job satisfaction of nurses in the state and the country:

- The government and hospital management should reduce political activities in the health-care ministry as well as hospitals and ensure that socio-political system will not impede the commitment and satisfaction of nurses in the hospitals. Some individuals are good at playing politics in the workplace to their advantage and at the detriment of others. Whatever gains individuals use in the game of politics to achieve their motive are always a loss to their opponent. Therefore, the sociopolitical climate should be attractive to all and sundry in hospitals especially when it comes to the working condition and supervision in tertiary hospitals.

- Government and management of tertiary hospitals should ensure that organisational support is provided continuously to health-care workers in Nigerian hospitals. The incidence that took away nurses' lives on the job especially during the Ebola outbreak of the year 2014 would not have happened if appropriate administrative and managerial support were given promptly.

- Management of hospitals need to also address the incidence of supervision of subordinates. There should be equal treatment to everyone and there should be no preferential treatment to some set of people if effective patients' outcome will be achieved. There should not be partial supervision because its absence will create an atmosphere that will foster efficient socio-camaraderie at work.

- Above all, the management of health-care facilities and hospitals should from time to time, create a pleasant environment in the workplace which will influence healthcare motivation, career decisions, relationship with co-workers, future growth and advancement in their profession.

\section{Implication for practice}

The outcome of this study in comparison with other similar studies in Europe and America clearly indicates that Nigerian nurses relatively differ with other nurses of the world. Salary and reward system are central to them than any other factors in the workplace. This is because of the socio-economic nature of the developing nation that Nigeria is categorised with. Also, career advancement and promotion stimulate Nigerian nurses to be satisfied at work and by extension reflect in quality service delivery to patients and attendees of the hospitals. This is because promotion usually comes with a higher salary and reward increase. Consequently, these two factors are key to Nigerian nurses when compared to other health-workers and Nurses across the world. 
RAMJ

14,1

\section{References}

Adegoke, A.A., Atiyaye, F.B., Abubakar, A.S., Auta, A. and Aboda, A. (2015), "Job satisfaction and retention of midwives in rural Nigeria", Midwifery, Vol. 31 No. 10, pp. 946-956.

Aiken, L.H. and Patrician, P.A. (2000), "Measuring organisational traits of hospital: the revised nursing work index", Nursing Research, Vol. 49 No. 5, pp. 146-153.

Aiken, L.H., Sloane, D.M., Bruyneel, L., Van den Heede, K. and Sermeus, W. (2013), “Consortium nurses' reports of working conditions and hospital quality of care in 12 countries in Europe", International Journal of Nursing Studies, Vol. 50 No. 2, pp. 143-153.

Akinwale, O.E. (2019), "Employee voice: speaking up in the organisation as a correlate of employee productivity in the oil and gas industry - an empirical investigation from Nigeria", Serbian Journal of Management, Vol. 14 No. 1, pp. 97-121.

Arnetz, B.B. (2011), "Psychosocial challenges facing health workers of today", Social Science and Medicine, Vol. 5 No. 3, pp. 47-59.

Arsalani, N., Fallahi-Khoshknab, M., Joseph, M. and Lagerstrom, M. (2012), "Iranian nursing staff's selfreported general and mental health-related to working conditions and family situation", International Nursing Review, Vol. 59 No. 3, pp. 416-423.

Baah, K. and Amoako, G.K. (2011), "Application of frederick herzberg's two-factor theory in assessing and understanding employee motivation at work: a Ghanaian perspective", European Journal of Business and Management, Vol. 3 No. 9, pp. 1-8.

Babbie, E. (2013), The Practice of Social Research, 13th ed., Belmont: Wadsworth/Thompson Learning.

Bempah, B.S.O (2013), "Determinants of job satisfaction among community health workers in Volta Region of Ghana", Public Policy and Administration Research, Vol. 3 No. 11, pp. 1-11.

Bakotic, D. and Babie, T. (2013), "The relationship between the working condition and job satisfaction: the case of croatian shipbuilding company", International Journal of Business and Social Science, Vol. 4 No. 2, pp. 23-35.

Bakotic, D. and Babic, T.B. (2013), "Relationship between working conditions and job satisfaction: The case of Croatian ship-building company", International Journal of Business and Social Science, Vol. 4 No. 2, pp. 206-213.

Blomberg, H. and Welander, J. (2019), "A narrative study of newly graduated registered swedish nurses' establishment in the profession and the portrayal of a healthcare organisation", Journal of Health Organization and Management, Vol. 33 No. 4, pp. 413-425, doi: 10.1108/ jhom-09-2018-0251.

Bryman, A. (2012), Social Research Methods, 4th ed., Oxford: Oxford University Press.

Cash, R., Wikler, D., Saxena, A. and Capron, A. (2009), Casebook on Ethical Issues in International Health Research, Geneva: World Health Organization.

Chamal, G.S. and Dilina, H. (2018), "Employee satisfaction and related factors among public health workers in Sri-Lanka: a case study on regional directorate of hambanthota", JOJ Nurse Health Care, Vol. 8 No. 4, pp. 1-7.

Chaudhury, S. (2015), "Job satisfaction of hospital staff: an emerging challenge", Medical Journal of Dr. D.Y. Patil University, Vol. 8 No. 2, pp. 129 -138.

Chen, J.W. and Lu, K.M. (2012), “The role of job design and mechanism in motivating feedback-seeking behaviour in transportation service", The Service Industries Journal, Vol. 32 No. 13, pp. 2047-2057.

Choi, S.P., Cheung, K. and Pang, S.M. (2012), "Attributes of the nursing work environment as predictors of registered nurses' job satisfaction and intention to leave", Journal of Nursing Management, Vol. 21 No. 3, pp. $12-29$.

Coakes, S. (2005), SPSS: Analysis without Anguish, 1st ed. Miltin, Old: Wiley Australia. 
Coker, O.O., Coker, A.O. and Onuoha, B. (2011), "A study on job satisfaction among clinical and nonclinical hospital staff in a teaching hospital in Lagos", Nigeria. East Efrica Journal of Public Health, Vol. 8 No. 4, pp. 299-302.

Darren, G. and Paul, M. (2012), IBM SPSS Statistics 19 Step by Step. A Simple Guide and Reference, 12th ed., Pearson.

De Cooman, R., Stynen, D., Van den Broeck, A., Sels, L. and De Witte, H. (2013), "How job characteristics relate to need satisfaction and autonomous motivation: implication for work effort", Journal of Applied Social Psychology, Vol. 43 No. 6, pp. 1342-1352.

Dixit, V. and Bhati, M. (2012), "A study about employee commitment and its impact on sustained productivity in Indian auto-component industry", European Journal of Business and Social Science, Vol. 1 No. 6, pp. 34-51.

Edem, M.J., Akpan, E.U. and Pepple, N.M. (2017), "Impact of workplace environment on health workers", Occupational Medicine and Health Affairs, Vol. 5 No. 2, pp. 1-5.

Ebuehi, O.M. and Campbell, P.C. (2011), "Attraction and retention of qualified health workers to rural areas in Nigeria: A case study of four LGAs in Ogun State", The International Electronic Journal of Rural and Remote Health Research, Education Practice and Policy, Vol. 11, pp. 2047-2057.

Edoho, S.P., Bamidele, E.O., Neji, O.I. and Frank, A.E. (2015), "Job satisfaction among nurses in public hospital in calabar, Cross River state, Nigeria", America Journal of Nursing Science, Vol. 4 No. 4, pp. 231-237.

Eme, O.I., Uche, O.A. and Uche, I.B. (2014), "Building a solid health care system in Nigeria: challenge and prospects", Academic Journal of Interdisciplinary Studies, Vol. 3 No. 6, pp. 501-510.

Ezeja, E.B., Azodo, C.C., Ehizele, A.O., Ehigiator, O. and Oboro, H.O. (2010), "Assessment of job satisfaction and working conditions of Nigerian oral health workers", International Journal of Biomedical and Health Sciences, Vol. 6 No. 3, pp. 143-150.

Fitzpatrick, J.J. (2012), "Registered nurse job satisfaction and satisfaction with the professional practice model", Journal of Nursing Management, Vol. 20 No. 2, pp. 260-265.

Ghaffari, M., Alinaghizadeh, H., Ghalichi, L., Pournik, O. and Vingard, E. (2017), "Assessment of the psychosocial work environment among health care workers and its association with work and socio-economic status", Archives of Neuroscience, pp. 1-13.

Goetz, K., Campbell, S.M., Steinhaeuser, J., Broge, B., Willms, S. and Szecsenyi, J. (2011), "Evaluation of job satisfaction of practice staff and general practitioners: an exploratory study", BMC Family Practice, Vol. 12 No. 1, pp. 411-417.

Goetz, K., Marx, M., Marx, I., Brodowski, M., Nafula, M., Prytherch, H., Omogi Awour, I.K. and Szecsenyi, J. (2015), "The working atmosphere and job satisfaction of health care staff in Kenya: an exploratory study", Biomed Research International, Vol. 2015, pp. 1-7.

Hackman, J.R. and Oldham, G.R. (1976), "Motivation through the design of work: test of a theory", Organizational Behavior and Human Performance, Vol. 16 No. 2, pp. 250-279.

Hackman, J.R. and Oldham, G.R. (1980), Work Redesign, Reading, MA: Addison-Wesley.

Hair, J.F., Black, W.C., Babin, B.J. and Anderson, R.E. (2014), Multivariate Data Analysis, 7th ed., Pearson Education Limited.

Halepota, J.A. and Shah, N. (2011), "An empirical investigation of organizational antecedents on employee job satisfaction in a developing country", Transforming Government: People, Process and Policy, Vol. 5 No. 3, pp. 280-294.

Heponiemi, T., Kuusio, H., Sinervo, T. and Elovainio, M. (2011), “Job attitudes and well-being among public vs private physicians: organizational justice and job control as mediators", The European Journal of Public Health, Vol. 21 No. 4, pp. 520-525.

Jandaghi, G., Mokhles, A. and Bahrami, H. (2011), "The impact of job security on employees' commitment and job satisfaction in qom municipalities", African Journal of Business Management, Vol. 5 No. 16, pp. 6853-6858. 
RAMJ

14,1

Kever, T.R., Oyibo, S.S., Gana, A.M., Ukende, F.J., Damkor, P.I. and Danlandi, S. (2018), "Survey of factors influencing job satisfaction among nurses in ahmadu bello university teaching hospital zaria", Nigeria. Asian Journal of Research in Nursing and Health, pp. 1-14.

Khunou, S.H. and Davhana-Maselesele, M. (2016), "Level of job satisfaction amongst nurses in the North-West province, South-Africa. Post-Occupation specific dispensation”, Curationis, Vol. 39 No. 1, pp. 1-10.

Kim, J.M. (2015), "The difference in life satisfaction and job satisfaction of nursing teachers depending on their socio-demographic characteristics", Advanced Science and Technology Letters, Vol. 103, pp. 197-201.

Kovnet, C.T., Brewer, C.S., Fatehi, F. and Jun, J. (2014), "What does the nurse turnover rate mean and what is the rate?", Policy Politics and Nursing Practice, Vol. 15 Nos 3/4, pp. 64-71.

Labarda, M.P. (2011), "Career shift phenomenon among doctors in tacloban city, Philippines: lessons for retention of health workers in developing countries", Asia Pacific Family Medicine, Vol. 10 No. 1, pp. 13-21.

Lane, K., Esser, J., Holte, B. and Anne, M.M. (2010), "A study of nurse job satisfaction in community colleges in Florida", Teaching and Learning in Nursing, Vol. 5 No. 1, pp. 16-26.

Lorber, M. and Savic, S. (2012), "Job satisfaction of nurses and identifying factors of job satisfaction in slovenian hospitals”, Croatian Medical Journal, Vol. 53 No. 3, pp. 263-270.

Luenendonk, M. (2017), "Understanding the job characteristics model (including job enrichment)", available at: www.cleverism.com/job-characteristics-model/ (accessed 06/03/2020).

Lunenburg, F. (2011), "Motivating by enriching jobs to make them more interesting and challenging", International Journal of Management, Business and Administration, Vol. 15 No. 1, pp. 1-11.

Kramer, M. and Hafner, L. (1989), "Shared values: impact on staff nurse job satisfaction and perceived productivity”, Nursing Research, Vol. 38 No. 3, pp. 172-177.

Malik, N. (2011), "Study on job satisfaction factors of faculty members at the university of Balochistan", International Journal of Academic Research, Vol. 3 No. 1, pp. 34-41.

Marinova, S.V., Peng, C., Lorinkova, N., Van Dyne, L. and Chiaburu, D. (2015), "Change oriented behaviour: a meta-analysis of individual and job design predictors", Journal of Vocational Behavior, Vol. 88, pp. 104-120.

Maulabakhsh, R. and Raziq, A. (2015), "Impact of working environment on job satisfaction”, Procedia Economics and Finance, Vol. 23, pp. 717-725.

Murta, S.G., Sanderson, K. and Oldenburg, B. (2011), "Process evaluation in occupational stress management programs: a systematic review", American Journal of Health Promotion, Vol. 21 No. 4, pp. 248-254.

Nahrgang, J.D., Morgeson, F.P. and Hofman, D.A. (2011), "Safety at work: a meta-analytic investigation of the link between job demands, job resources, burnout, engagement, and safety outcomes", Journal of Applied Psychology, Vol. 96 No. 1, pp. 71-94.

Ogbolu, Y., Johantgen, M.E., Zhu, S. and Johnson, J.V. (2015), "Nurse reported patient safety in low resource setting: a cross-sectional study of MNCH nurse in Nigeria", Applied Nursing Research, Vol. 28 No. 4, pp. 341-346.

Oldham, G.R. and Hackman, J.R. (2010), "Not what it was and not what it will be: the future of job design research", Journal of Organizational Behavior, Vol. 31 Nos 2/3, pp. 463-479.

Osibanjo, A.O., Abiodun, A.J. and Adeniji, A.A. (2014), "Impact of job environment on job satisfaction and commitment among nigerian nurses", Journal of South African Business Research, Vol. 3 No. 4, pp. 1743-1752.

Oyeleye, O., Hanson, P.O., O'Connor, N. and Dunn, D. (2013), "Relationship of work incivility, stress, and burnout on nurses' turnover intentions and psychological empowerment", Journal of Nursing Administration, Vol. 43, pp. 536-542. 
Oyetunde, M.O. and Ayeni, O.O. (2014), "Exploring factors influencing recruitment and retention of nurses in Lagos state, Nigeria within the year 2008 and 2012", Open Journal of Nursing, Vol. 4 No. 8, pp. 590-601.

Parker, S.K. (2014), "Beyond motivation: Job and work design for development, health, ambidexterity, and more", Annual Review of Psychology, Vol. 65 No. 1, pp. 661-691.

Parker, S.K., Holman, D. and Van den Broeck, A. (2017), "Word design influences: a synthesis of multilevel factors that affect the design of work", Academy of Management Annals, Vol. 11 No. 1, pp. 257-308.

Parker, S.K., Wall, T.D. and Cordery, J.L. (2011), "Future work design research and practice: towards an elaborated model of work design", Journal of Occupational and Organizational Psychology, Vol. 74 No. 4, pp. 413-440.

Sell, L. and Cleal, C. (2011), "Job satisfaction, work environment, and rewards: motivational theory revisited", LABOUR, Vol. 25 No. 1, pp. 34-47.

Serdar, T., Derek, L., Unic, A., Marijancevic, D., Markovic, D. and Primorac, A. (2013), "Occupational exposures in healthcare workers in university hospital dubrava a - 10-year follow-up study. Centre for", Central European Journal of Public Health, Vol. 21 No. 3, pp. 150-154.

Slater, P., O'Halloran, P., Connolly, D. and McCormack, B. (2010), "Testing of the factor structure of the nursing work index-revised", Worldviews on Evidence-Based Nursing, Vol. 7 No. 3, pp. 123-134.

Stringer, C., Didham, J. and Heivanthampillai, P. (2011), "Motivation, pay satisfaction and job satisfaction on front-line employees", Qualitative Research in Accounting and Management, Vol. 8 No. 2, pp. 161-179.

Taber, T.D. and Taylor, E. (1990), "A review and evaluation of psychometric properties of the job diagnostic survey", Personnel Psychology, Vol. 43 No. 3, pp. 467-500.

Tement, S. and Korunka, C. (2013), "Does trait affectivity predict work-to-family conflict and enrichment beyond job characteristics?”, The Journal of Psychology, Vol. 147 No. 2, pp. 197-216.

Ugwa, A.E., Muhammad, L.M. and Ugwa, C. (2014), "Job satisfaction among nurses and doctors in a tertiary hospital in North-West Nigeria: a cross-sectional study", International Journal of Hospital Research, Vol. 3 No. 1, pp. 11-18.

Vahey, D.C., Aiken, L.H., Sloane, M., Clarke, S.P. and Vargas, D. (2004), "Nurse burnout and patient satisfaction", Medical Care, Vol. 42 No. 2, pp. 57-66.

Van den Broeck, A., Schreurs, B., Guenter, H. and van Emmerik, I.H. (2015), "Skill utilization and wellbeing: a cross-level story of day-to-day fluctuations and personal intrinsic values", Work and Stress, Vol. 29 No. 3, pp. 306-323.

Van den Broeck, A., Van Ruysseveldt, J., Vanbelle, E. and De Witte, H. (2013), "The job demandsresources model: overview and suggestions for future research", in Bakker, A.B. (Ed.), Advances in Positive Organizational Psychology, (Vol. 1, pp. 83-105), Emerald, Bingley.

Van der Doef, M., Mbazzi, F.B. and Verhoeven, C. (2012), "Job condition, job satisfaction, somatic complaints and burnout among east african nurses", Journal of Clinical Nursing, Vol. 21 Nos 11/12, pp. $1763-17775$.

Wallace, J.E., Lemaire, J.B. and Ghali, W.A. (2012), "Physician wellness: a missing quality", The Lancet, Vol. 374 No. 9702, pp. 1714-1721.

\section{Further reading}

Bakker, A.B., Boyd, C.M., Dollard, M., Gillespie, N., Winefield, A.H. and Stough, C. (2010), "The role of personality in the job demands-resources model", Career Development International, Vol. 15 No. 7, pp. 622-636.

Iliopoulos, E. and Pripoa Ras, C.V. (2011), "The effect of internal marketing on job satisfaction in health services: a pilot study in public hospitals in Northern Greece", BMC Health Service Research, Vol. 11 No. 1, pp. 261-274. 
RAMJ

14,1

92

\begin{abstract}
About the authors
Olusegun Emmanuel Akinwale is currently $\mathrm{PhD}$ Research Scholar in Organisational Behaviour at University of Lagos, Department of Business Administration, Faculty of Management Sciences. He is the corresponding author for this paper and has peer-reviewed research papers for journals such as Serbian Journal of Management, Scientific Annals of Economics and Business; Journal of Health Organisational and Management, (Emerald Publishing Company) International Journal of Workplace Health Management (Emerald Publishing Company), and Rajagiri Management Journal (Emerald Publishing Company) to mention but a few. His research interest areas include but are not limited to industrial organisational psychology, research methods, general management and strategy, organisational behaviour, managerial psychology, human resources management, social psychology, gender psychology and gender inequality. Olusegun Emmanuel Akinwale is the corresponding author and can be contacted at: akinwaleolusegun@yahoo.com

Olusoji James George is Associate Professor of organisational behaviour and strategy at University of Lagos, Department of Business Administration. He has $\mathrm{PhD}$ degree from Brunnel University and has authored and co-authored several research articles from international journals in Africa. He has featured in several publications both foreign and local journals.
\end{abstract}

For instructions on how to order reprints of this article, please visit our website: www.emeraldgrouppublishing.com/licensing/reprints.htm Or contact us for further details: permissions@emeraldinsight.com 